\title{
Monopoly of legal provisions
}

\author{
Anna Konstantinovna Sheremetyeva ${ }^{1 *}$, Zoya Fedorovna Sofrina ${ }^{2}$, Artem Aleksandrovich \\ Gamaley $^{3}$, and Natalia Nikolaevna Novopashina² \\ ${ }^{1}$ Federal State Educational Institution of Higher Education Pacific National University, Department of \\ Civil Law and Entrepreneurship, Khabarovsk, Russia \\ ${ }^{2}$ Far Eastern Branch of the Federal State Educational Institution of Higher Education Russian State \\ University of Justice, Department of Civil Procedure Law, Khabarovsk, Russia \\ ${ }^{3}$ Far Eastern Branch of the Federal State Educational Institution of Higher Education Russian State \\ University of Justice, Department of Theory and History of Law and State, Khabarovsk, Russia
}

\begin{abstract}
The existing defect of the legal field in the form of the inconsistency of the norms that make it up, gives rise to inconsistency, imbalance of the main social regulator of social relations. Building the normative material without analysing the need to create a separate regulator, as well as the obligation to establish a relationship with existing norms, determined the significance of such a study. The definition of competition of norms is an object of scientific research quite often. However, the content of this category and its law enforcement significance, in our opinion, have not been established quite correctly. The presence of competition of norms indicates the inconsistency of legal regulators with the principles of certainty of law, fairness and stability of legal regulation, which affects the effectiveness of laws. The research patterns are due to the need for a systematic analysis of this institution in order to identify uncovered aspects in the construction of a clear, systemic and interdependent system of legal regulation. Purpose of the research. The importance of developing fundamentally new approaches to the institution of uncertainty mediated by the phenomenon of competition to overcome the imbalance of the existing legal system, in connection with the existing need to present the normative material unambiguously and clearly. Methods. In the course of the study, in combination with a complex and systemic analysis, the following general scientific methods of cognition were used: dialectical, hermeneutic, and synthesis methods, the method of ascent from the abstract to the concrete, and the method of generalization and comparison. Results and novelty. Competition of norms is the result of an incorrect construction of the system of legal norms indicating a certain artificiality of this definition regarding the possible flexibility of the legal system. In our opinion, an increase in monopoly and individualized norms will lead to a systematic nature of the normative material, as well as an increase in confidence in it on the part of all participants in legal relations. The certainty of law must become a legal axiom.
\end{abstract}

Keywords: efficiency and force of law, legal certainty, construction of law.

${ }^{*}$ Corresponding author: sher198029@rambler.ru 


\section{Introduction}

Certainty as a model of the understandable and predictable is the most important regulator that ensures the stability of any relationship. Law, of course, is a toolkit that creates opportunities for building a system of regulation in the society. Besides, stability and certainty in relations should be achieved with its help.

Pokrovskii considered the certainty of legal regulators as an unconditional and natural human right. In particular, he pointed out: "Logically, the right to certainty of legal norms is one of the inalienable rights of human life which one can only imagine; without it, in essence, there can be no question of any right" [1, p. 91].

The legal framework should ensure that the modelling of relationships is as clear and predictable as possible in terms of legal consequences. Inconsistency of law, the use of various legal structures to regulate identical relations creates obstacles in adequate legal implementation.

The legal qualification of legal relations is based on the search for the norms of law by which they are regulated, and acts as the main action in the law enforcement cycle. Legal qualification is a thought process carried out in order to determine the conformity of circumstances to the action of a specific legal norm.

The accuracy of the legal assessment depends on the maximum guaranteed certainty of the construction of the regulatory material. The presence of conflicting legal norms aggravates the process of inconsistency and enhances the effect of the presence of legal entities unnecessarily. In this case, uncertainty arises in connection with the need to make the choice of the norm to be applied. This problem seems to be the most urgent in the field of bringing people to justice, since the institution of competition is most studied in this particular area, but the presence of such norms leads to uncertainty and discretion.

The existence of competing norms in the legal system has been studied for a long time. However, in our opinion, this institution has a negative character, since we can talk about the relativity of the category of competition, which is due to the vagueness of its content and insufficient elaboration of the methodological relationship with such legal definitions as conflict, interpretation of law, construction, and legal certainty. Achievement of regulatory transparency is seen rather not in the search for the true content of all the above categories, but in the implementation of an expedient systematization of existing norms.

\section{Results}

To build a scientific typology of systematizing the existing normative material, one should take into account the essential criteria for building a legal system.

The problem of qualifying legal relations is reduced to the following:

- the abundance of evaluative, imprecise, ambiguous terms and concepts including in criminal law;

- the existence of single-industry norms that regulate similar relations but do not reflect the conceptual clarity of their interaction in the course of law enforcement;

- the presence of different sector profile norms containing different mechanisms of legal regulation of legal relations of the same type.

It is customary to solve these problems with the help of the institution of competition as a necessary element of legal regulation. Competition as a legal phenomenon is used by various branches of law and is integrated not only into legal science. It exists in various spheres of life including political, economic, and financial.

The legislation of the Russian Federation defines the category competition as a rivalry. The law considers this phenomenon exclusively as a positive and pursuing the goal "... to 
exclude or limit the ability of economic entities to unilaterally influence the general conditions of circulation of goods".

Within the framework of legal science, most authors point out that the institution of competition is important for study from a theoretical and practical point of view, since there is no uniform understanding of competition as a legal phenomenon, criteria for its differentiation from collision have not been developed, and there is also no consensus regarding the types and techniques to overcome it.

According to Arzumanyan, the competition of legal norms presupposes the regulation of relations by several prescriptions that do not contradict each other [2].

There is also an opinion that competition acts as a legally significant result of the existence of norms that are equal in legal force regulating relations, but only one of them is sufficient and necessary to regulate the legal relationship [3, p. 112].

The above points of view do not reflect that the presence of several norms leads to their confrontation and the problem of choosing the right legal regulator [4, p. 204].

Despite the apparent elaboration of this definition and the proof of the importance of existence, the authors still see the possibility of excluding it with a proper conceptual approach in the formation of normative material. Eliminating the rivalry of norms and a thorough understanding of the uniqueness of each of them will lead to the creation of monopolized norms that differ in individuality.

\section{Discussion}

Positive law is immanently blank, and therefore the complete certainty of positive law is unattainable [5].

Of course, it is quite difficult to create a perfect legal mechanism, but taking into account the natural-legal principles which are a guideline for the creation of the entire legal system, it is possible to approach the ideal.

The lack of certainty of legal norms has been discussed for a long time and in different directions. In some way, certainty as a criterion of a legal norm is formulated in a number of Decisions of the Constitutional Court of the Russian Federation (including No. 3-P dated 25.04.1995, No. 11-P dated 15.07.1999, No. 6-P dated 25.04.2001, No. 14-P dated 16.07.2004). Certainty is a manifestation of the principle of equality of all before the law and the court, since only a uniform understanding and application to all participants reflects the implementation of this principle. Uncertainty of the content of a legal norm, on the contrary, allows for the possibility of unlimited discretion in the process of law enforcement and inevitably leads to arbitrariness, that is, to a violation of the principles of equality, as well as the rule of law [6].

America's constitutional law adopted the Void-for-Vagueness Doctrine which implies that an overly imprecise and vague law is invalid.

The discussion about the possibility of achieving full certainty and the need for this has been going on for a long time. So, Tillers points out that uncertainty is a common feature of law in general and legal systems [7]. Certainly, many authors still consider their predictability to be a necessary element of the norms [8-11]. So, they agree with the opinion that the law should be certain, not vague [12]. There is also an opposite opinion indicating that uncertainty has its own merits, and the law does not have to be foreseeable [13].

The authors believe that the law should strive for consistency, and this is especially important in the aspect of criminal legislation, in which manifestation of ambiguity can be regarded as injustice [14-15]. 


\section{Conclusion}

As a result, I would like to refute the possibility of the existence of competition as a necessary element of legal regulation. The conclusion follows from the ambiguity in determining the criterion of the positiveness of this legal phenomenon, since some excessive or unjustified competition leads to a gap, and the absence of such a gap has a positive effect on the normative material. In addition, there are enough norms that are particular cases of one another and, with sufficient research, can be combined into one to eliminate the need to search for the order of their application. Besides, regulations often contain categories that are not legally enshrined and are interpreted differently depending on the industry. A no less problem is created by evaluative definitions mostly leading to discretion and individual understanding and, as a result, ambiguity, inaccuracy and uncertainty.

\section{References}

1. A. Pokrovskii, Osnovnye problemy grazhdanskogo prava [Basic Problems of Civil Law] (Moscow, 2003)

2. A.E. Arzumanyan, Konkurenciya norm rossiiskogo prava (voprosy teorii i praktiki) [Competition of the Norms of Russian Law (theory and practice)], Abstract of a PhD thesis in Law (Saratov, 2009)

3. A.S. Eremenko, Primenenie grazhdanskogo zakona. Propedevticheskii ocherk [Application of Civil Law. Propedeutic sketch] (Moskow, 2010)

4. N.I. Matuzov, Aktualnye problemy teorii prava [Actual Problems of the Theory of Law] (Saratov, 2003)

5. A.G. Karapetov, Borba za priznanie sudebnogo pravotvorchestva v evropeiskom i amerikanskom prave [Struggle for the Recognition of Judicial Law-making in European and American Law] (Statut, Moskow, 2011)

6. Yu.M. Lermontov. Postateinyi kommentarii k chasti pervoi Nalogovogo kodeksa Rossiiskoi Federacii [Article-by-article Commentary to the First Part of the Tax Code of the Russian Federation.], SPS ConsultantPlus (2019). Accessed on: April 14, 2021. [Online]. Available:

http://www.consultant.ru/cons/cgi/online.cgi?req=doc\&base $=\mathrm{CMB} \& \mathrm{n}=18168 \# 071825$ 59404880435

7. P. Tillers. Probability and Uncertainty in Law (2003). http://dx.doi.org/10.2139/ssrn.738764

8. J.W. Evans, A.L. Gabel, American Business Law Journal, 57(3), 593-646. https://doi.org/10.1111/ablj.12169

9. G.D. Mattiacci, B. Deffains, JITE Jahrgang, 163(4), 627656 (2007). https://doi.org/10.1628/093245607783242990

10. U. Mattei, F. Pulitini, A competitive model of legal rules, in A. Breton, G. Galeotti, P. Salmon, R. Wintrobe (eds.), The Competitive State. International Studies in Economics and Econometrics, vol. 21 (Springer, Dordrecht, 1991). https://doi.org/10.1007/978-94-009-0645-7_12

11. S. Reis-Dennis, M.S. Gerrity, G. Geller, Tolerance for Uncertainty and Professional Development: a Normative Analysis, J Gen Intern Med (2021). https://doi.org/10.1007/s11606-020-06538-y

12. D. Prendergast. DULJ. 7 (2017). http://dx.doi.org/10.2139/ssrn.341161 
13. T. Baker, A. Harel, T. Kugler, Iowa Law Review, 89, 443 (2004). http://dx.doi.org/10.2139/ssrn.380302

14. Y. Katsoulacos, D. Ulph, Legal uncertainty, competition law enforcement procedures and optimal penalties, Eur J Law Econ 41, 255-282 (2016). https://doi.org/10.1007/s10657-015-9504-1

15. T. Gegeliya, Prohibition of Uncertainty of the Law in Contemporary Criminal Law Accessed on: April 26, 2021. [Online]. Available:

https://www.researchgate.net/publication/322684424_Prohibition_of_Uncertainty_of_t he_Law_in_Contemporary_Criminal_Law 